\title{
Supply - side Reform: A New Perspective of Ideological and Political Education Reform in Colleges and Universities
}

\author{
Huifang $\mathrm{Hu}$ \\ Guangdong University of Science \& Technology, Dongguan, China \\ 459592711@qq.com
}

Keywords: supply side reform; ideological and political education in colleges and universities; status quo; reform path

\begin{abstract}
In modern society, politics, economy and education are closely linked. The "supply side reform" in economy will inevitably bring about educational reform. Schools, teachers and student organizations as the ideological and political education in colleges and universities "supply" the main body, plays an important role. However, at present, the supply of the ideological and political education in colleges and universities is affected by the factors such as the teaching system, the teachers' ability and the quality of the mass organizations, and there are still some shortcomings. It is the urgent task of ideological and political education reform to find out the effective solutions. Now the main points of this paper to explain the form of a form to help clarify the contents of the article as soon as possible.
\end{abstract}

\section{The Importance of the Subject of "Supply" of Ideological and Political Education in Colleges and Universities}

The supply side is relative to the demand side, the ideological and political education as an important part of higher education should also be in the social and economic environment changes and development in a timely manner to make adjustments, and supply side reform for the ideological and political education reform Development provides a new perspective. The core of the supply side reform is to protect and create effective supply, while the key to ensuring effective supply, first, the quality of supply, the second is the supply side. The supply of ideological and political education in colleges and universities, including schools, teachers, student organizations, including the ideological and political education of college students organization and individual. The supply subject of colleges and universities has the characteristics of diversity and hierarchy, and plays an important role in ideological and political education in colleges and universities.

Educational philosophy and teaching system is an important guarantee for ideological and political education in colleges and universities

The school curriculum, assessment methods are the key factors affecting ideological and political education. College ideological and political education theory courses are used in public courses, elective courses, or fine class form will have different effects. To a certain extent, the degree of strictness of the assessment method has affected the degree of importance of the students as the demand side of ideological and political education. Therefore, the scientific concept of education and a complete teaching system, is to obtain good ideological and political education in colleges and universities effective protection.

The professional competence of teachers and their own quality of ideological and political education is the core strength

As one of the main subjects of ideological and political education, teachers have more direct teaching and educating responsibilities. Teachers and students face to face with the class, counseling, Q \& A, and thus the professional competence of teachers and personal qualities affect the students active acceptance of ideological and political education, and the extent of the actual impact of education. In daily teaching, teachers' knowledge and ability level, class style, attitude towards students, have a direct impact on the performance of students in the classroom. Besieged Bo, humorous, approachable, is generally recognized and appreciated by the students of the quality of 
teachers.

\section{The Present Situation of Ideological and Political Education "Supply Side" in Colleges and} Universities

Teaching conditions are limited and the degree of attention is low, hindering the development of teaching in schools

At present, most colleges and universities in China is in the rising period of development, the expansion of the new campus of the necessary human and material resources, leading to the school facilities in the teaching of ideological and political education is not a dedicated space and place-assisted teaching. Ideological and political education theory has a boring, rigid characteristics, but also need to support the school facilities in teaching. "Mao election", modern history and other courses not only need to teach in class, but also need students to have a more intuitive "look." Although multimedia has been used in teaching, but the teaching effect is not satisfactory.

The heavy task of scientific research and teacher professionalism is very different, limiting the teaching ability of teachers

At present, the evaluation and assessment of teachers 'titles in China are mainly based on the teachers' scientific research. Indeed, the level and number of scientific research can be used as a measure of whether teachers have higher standards of the title, but by no means the most important criteria. The more important duty of teachers is to educate people through teaching. Teachers in the tilt to the scientific research, investment in teaching and students will inevitably reduce the energy, the positive impact on students will be reduced. Teachers are busy with research and lack of skills, resulting in lack of effectiveness of ideological and political education.

\section{The Reform Path of "Supply Side" of Ideological and Political Education in Colleges and Universities}

\section{School level}

1) Hardware facilities are the guarantee for the smooth development of teaching work.

In order to improve the ideological and political education, schools should increase investment in education, improve teaching conditions. Some scholars believe that: "To some extent, can be said that demand is born, is not how to mobilize, good things no one likes, the key is that we can provide good things that can continue to provide good things that can provide more and more "While increasing investment in education in the short term to increase the economic burden of the school, but in the long run, its positive impact and return sufficient to balance the current stage of the pressure.

2) Innovative personnel training mechanism, the cohesion of teachers together.

On the one hand, it is about the future of the students; on the other hand, it is closely linked with the future of the country and the society. The construction of teachers' team plays an important role in personnel training. First, the concept of innovation is the foundation. Lenin said: "No revolutionary theory, there is no revolutionary movement." College ideological and political education personnel training mechanism, teacher team building, is to fundamentally improve the level of awareness, improve people's ideological and moral qualities. Second, method innovation is the key. With the correct and advanced concept, the ideological and political education of personnel training and teacher team building in the method should enhance the effectiveness and improve the pertinence. Third, institutional innovation is to protect. Strict and complete system, is the ideological and political education of personnel training and the construction of a strong contingent of teachers protection.

\section{Teacher level}

1) Change the teaching philosophy, teaching focuses on educating people.

Teachers face the pressure of scientific research and lead to reduced investment in teaching. Improve the "supply" the status quo, teachers can change the teaching philosophy. The concept mentioned here refers to the teacher's ideological and political education courses for students should 
focus on education, not just to impart knowledge of books. Most of the students of liberal arts classes can learn their own theory, but learning does not mean that the understanding and application to practice, the need for teacher inspiration and guidance. College students are in the life and the formation of an important period of values, ideological and political education at this stage has a pivotal role. Therefore, as ideological and political education workers and communicators of teachers, bear more of this responsibility and obligation.

\section{2) Change teaching style, enhance personal charm.}

Teacher's personal charm on the impact of students is self-evident. In most cases, students will appreciate the teacher's teaching style, so that the courses they have a keen interest in learning, and even change the direction of student learning and career. Some teachers in the classroom next to bibcock, the impact of knowledge to students; some teachers humorous, with character impact on students; some teachers frequently interact to influence students thinking. These different types of teachers have a common characteristic, is loved by the students, students can resonate, have a good impact.

\section{Student community level}

1) enhance the overall quality of membership, improve the quality of community activities.

Student associations are part of school management and are inevitably subject to school rules and regulations. In order to ensure the community has more independence, community managers and their members should be to enhance the overall quality of members as the starting point, and continuously improve the quality of community activities. The vitality of student associations from the quality of membership, only high-quality members to expand the impact of associations for the community to establish a good image. Therefore, before enrollment, combined with the development of the community's own characteristics and the actual needs of the activities, strict checks, do a good job of membership review. To recruit members to be more concerned about community, ground training, and to develop a reasonable reward and punishment system. Enhance the level of student community activities, and enhance the orderly and normative activities. At the same time, in the form of activities to do homework, to ensure that the activities of the educational, entertaining and intellectual effect. Conditional student organizations can also employ full-time event planners to further enhance the quality of community activities.

2) Innovate the development mechanism of student associations and broaden the development path of community.

The development of student associations is not limited to the school, but also try to more development model, choose a different path of development. For example, you can choose cross-school cooperation, choose the same or different societies of other institutions to cooperate to achieve resource sharing and complement each other, and promote the development of student organizations. In addition, within the community can be an in-depth study of community development mechanism, from the composition of personnel and the internal environment point of view, consider how to maximize the creativity and enthusiasm of students. As the main body of the "supply" of ideological and political education, student associations should be closely linked with the first class of colleges and universities, and should really regard college student societies as the "supply side" of ideological and political education in colleges and universities and effective ways.

\section{Conclusion}

In the context of China's advocacy of structural reforms in the supply side, education reform has come to a new stage of development. In the past, demand-side-oriented reform has failed to meet the needs of the actual development of ideological and political education in colleges and universities, and upgrading the quality of supply side has become the main way of educational reform.

Demand and supply are always two aspects of a continuum. It emphasizes supply-side reform. It is always necessary to combine demand and supply, and not to oppose and separate the two. To innovative educational philosophy, taking into account demand management and supply management, innovation and lead the formation of new ideological and political education needs. 
By analyzing the importance and status quo of the supply of ideological and political education in colleges and universities from the perspective of supply side, the countermeasures and suggestions to improve the status quo are put forward, with a view to provide reference and reference for the reform and development of ideological and political education in colleges and universities.

\section{References}

[1] Yu Dianli. To supply the reform of the publishing industry to promote the modernization of the market [N]. China Publishing Journal, 2016-03-18.

[2] Tao Xiping .21st century curriculum agenda: background, connotation and strategy [J]. Comparative Education Research, 2016 (2): 1-5.

[3] Cui Fusheng, Zeng Zexin Analysis of the Current Situation and Development of College Students' Associations [J] .Jiangxi Social Sciences, 2003 (11): 241-224.

[4] LiuYuYing, ChenMei. "Supply side reform" from the perspective of vocational school students moral education path analysis [J] Vocational Education Forum, 2016 (11): 19-22.

[5] Zhang Yun. Interpretation of Supply Side Structural Reform from the Perspective of Supply and Structure [J] .Politics of Political Economy, 2016 (2): 219-221.

[6] Yuan Yuan. Supply side change: the basic strategy of ideological and political education of ethnic minority college students [J]. Guizhou Ethnic Studies, 2016 (3): 227-231.

[7] Liu Yunsheng. Supply side structural reform: education how to do? [J] .Development of Education Research, 2016 (3): 1-7 [8] Shi-xu. Ideological and political education in universities should also be "supply side reform" thinking [N] Guangming Daily, 2016-03-16. 